\title{
Acute Pneumonia Characteristics in Children under Five Years of Age in Bamako, Mali
}

\author{
Fatoumata Dicko-Traoré1,2*, Abdoul Karim Doumbia1, Mariam Sylla',2, Mariatou Traoré1, \\ Djènèba Konatée1,2, Fatoumata Léonie Diakité1,2, Karamoko Sacko, ${ }^{1,2}$, Belco Maiga, ${ }^{1,2}$, Hawa Diall1, \\ Oumar Coulibaly', Pierre Togo' ${ }^{1}$, Fousseyni Traoré1,2, Abdoul Aziz Diakité1,2, Yacouba Toloba ${ }^{2,3}$
}

\author{
${ }^{1}$ Department of Pediatrics, CHU Gabriel Touré, Bamako, Mali \\ ${ }^{2}$ Faculty of Medicine and Odontostomatology, Bamako, Mali \\ ${ }^{3}$ Department of Pneumology, CHU Point G, Bamako, Mali \\ Email: *fatdickoped@gmail.com
}

How to cite this paper: Dicko-Traoré, F., Doumbia, A.K., Sylla, M., Traoré, M., Konaté, D., Diakité, F.L, Sacko, K., Maiga, B., Diall, H., Coulibaly, O., Togo, P., Traoré, F., Diakité, A.A. and Toloba, Y. (2019) Acute Pneumonia Characteristics in Children under Five Years of Age in Bamako, Mali. Open Journal of Pediatrics, 9, 7-18. https://doi.org/10.4236/ojped.2019.91002

Received: December 29, 2018

Accepted: January 13, 2019

Published: January 16, 2019

Copyright $\odot 2019$ by author(s) and Scientific Research Publishing Inc. This work is licensed under the Creative Commons Attribution International License (CC BY 4.0).

http://creativecommons.org/licenses/by/4.0/

\begin{abstract}
Pneumonia is the most common cause of mortality in child under five years of age. The objective of the study was to assess socio-demographic and clinical characteristics of children under 5 hospitalized for pneumonia. Material and method: We conducted a 6 months prospective study from June $1^{\text {st }}, 2016$ to December $31^{\text {st }}, 2016$ in the general pediatric service in the Pediatric Department of Gabriel Touré Teaching Hospital in Bamako, the capital city of Mali. Result: We have selected 63 cases of pneumonia according to our definition criteria, i.e. $2.2 \%$ of hospitalizations for children aged 1 to 59 months. The average age was 14 months. Infants under 2 years accounted for $82.53 \%$. The sex ratio was 1.2. Seventy eight percent came from an unfavorable socio-economic background. The majority of mothers were uneducated (71.42\%). Breastfeeding was exclusive up to 6 months in $50.79 \%$ of patients. Vaccination according to the national program was not up to date in $27 \%$ of patients. The average consultation time was 18 days. On admission, $81 \%$ of the patients had a fever, $93.64 \%$ had a tachypnea and $58.73 \%$ had crackling rales at pulmonary auscultation. Hypoxemia was present in $58.73 \%$. Severe anemia was present in $79.36 \%$. Radiologically, opacity was found in 42 patients $(66.66 \%)$. The blood culture was positive in $8.3 \%$. Beta-lactams were first-line prescribed in all patients. The case fatality rate was $9.52 \%$. The factors associated with mortality were age less than 14 months $(p=0.08)$, adverse socio-economic conditions $(\mathrm{p}=0.0003)$ and the presence of hypoxemia at the entrance $(p=0.01)$. Conclusion: Pneumonia remains major cause of morbidity and mortality in our context. Emphasis should be put on preventive measures.
\end{abstract}




\section{Keywords}

Acute Pneumonia, Children, Mortality, Mali

\section{Introduction}

Pneumonia is the most common cause of mortality in child under five years of age [1] [2]. The annual incidence in the industrialized countries is estimated between 36 and 40/1000 in children under 5 years [3]. Every year, 1.9 million children under 5 die from pneumonia mainly in developing countries [2]. Poor socio-economic conditions, chronic diseases, lack of vaccination, malnutrition, air pollution and inadequate and late care would contribute significantly to high pneumonia mortality [4] [5]. To reduce the mortality attributable to it, the World Health Organization (WHO) has implemented the global strategy for the management of acute respiratory infections in children under five. This is based on early clinical screening and rational use of antibiotic therapy in primary and peripheral hospitals [6].

In Bamako, the capital of Mali, pneumonia was the most frequent cause of hospital admission, representing $18 \%$ of total hospital admissions [7]. Acute respiratory infections represent $34 \%$ of admissions in children, and $15 \%$ of child hospitalizations in the Pediatric Department of Gabriel Touré Teaching Hospital, the national reference structure [8]. However in statistics, there is no information specific to pneumonia.

The aim of the study was to assess socio-demographic and clinical characteristics of children under 5 hospitalized for pneumonia in order to propose preventive measures.

\section{Material and Method}

We conducted a 6 months prospective study from June $1^{\text {st }}, 2016$ to December $31^{\text {st }}, 2016$ in the general pediatric service in the Pediatric Department of Gabriel Touré Teaching Hospital in Bamako, the capital city of Mali. The department is the highest reference structure in the country. Its provides the care of either children referred from all over the country at every level of the national health pyramid or those accompanied by their parents from the city of Bamako and its neighboring areas. The general pediatric ward has 62 beds and hospitalises an average of 2162 patients per year, of which $55 \%$ are referred by other health structures [8].

Children over one month and less than 5 years old who were hospitalized for pneumonia less than 14 days old and had a chest $\mathrm{x}$-ray were included.

Operationally:

- pneumonia has been defined according to the WHO in the presence of: cough and/or breathing difficulties, and tachypnea (breathing rate $\geq 60$ cycles per minute in children less than 2 months, $\geq 50$ cycles per minute between 2 
and 11 months and $\geq 40$ cycles per minute between 1 and 5 years) [9] [10].

- Radiological confirmation of pneumonia was made according to WHO guidelines [10] [11]. X-ray was blindly interpreted by two radiologists.

- Socio-economic conditions were appreciated with the Chauliac M and Ag Bendech method [12] [13]. This method is based on the residency, type of housing, profession of the child's father, and the family income. This allows us to classify the socio-economic ranking: favorable and unfavorable.

- Vaccination was evaluated according to the Expanded National Immunization Program.

- Severe malnutrition has been defined for a weight-to-size ratio $<-3$ ZScore [14].

- The diagnosis of human immunodeficiency virus (HIV) infection was made in the presence of a positive PCR-DNA before the age of 18 months or two positive serologies after the age of 18 months [15].

- Anemia has been called severe when hemoglobin $<8 \mathrm{~g} / \mathrm{dL}[16]$.

- Hyperleucytosis has been defined by a white blood cell count $>15,000 / \mathrm{mL}$ [16].

- C-Reactive Protein (CRP) was positive for $>6 \mathrm{mg} / \mathrm{L} \mathrm{[16].}$

- Fever was retained for axillary temperature above $38^{\circ} \mathrm{C}[16]$.

- Hypoxemia was retained for oximetry with pulse oximeter 90\% [16].

Were not included the children who presented wheezing at auscultation.

The variables studied were related to socio-demographic data (age, sex, socio-economic level, vaccination, pathological history, consultation time), clinical (cough, fever, respiratory distress, respiratory rate, crackling rales), radiological, biological (blood count and CRP), therapeutic and evolutionary. These data were collected using a survey sheet.

Data capture and analysis were done on SPSS version 20. For the analysis of prognostic factors the Fisher Test was used with a significance level of less than $5 \%$.

\section{Results}

During the study period 2875 children from 1 to 59 months old were hospitalized. We selected 63 cases of pneumonia according to our definition criteria, i.e. $2.2 \%$ of hospitalizations for children from 1 to 59 months. The average age was 14 months. Infants under 2 years accounted for $82.53 \%$. The sex ratio was 1.2 (34 boys and 29 girls). Thirty-three percent lived in the urban area of Bamako and $78 \%$ came from an unfavorable socio-economic background. The majority of mothers were uneducated (71.42\%). Breastfeeding was exclusive up to 6 months in $50.79 \%$ of patients. Vaccination according to the national program was updated in $27 \%$ of patients. A history of congenital heart disease and HIV infection was found in eight (12.69\%) and six (9.52\%) children, respectively. The main socio-demographic characteristics and antecedents are summarized in $\mathrm{Ta}-$ ble 1 . 
Table 1. Sociodemographic characteristics and background of children.

\begin{tabular}{|c|c|c|}
\hline Variables & Frequency $(n=63)$ & Percent \\
\hline \multicolumn{3}{|l|}{ Age } \\
\hline Average & 14 months & \\
\hline $1-12$ months & 38 & 60.31 \\
\hline $13-24$ months & 14 & 22.22 \\
\hline \multicolumn{3}{|l|}{ Sex } \\
\hline Male & 34 & 53.96 \\
\hline Female & 29 & 46.03 \\
\hline \multicolumn{3}{|c|}{ Level of education of the mother } \\
\hline Uneducated & 45 & 71.42 \\
\hline Primary & 16 & 25.39 \\
\hline \multicolumn{3}{|c|}{ Feeding mode before 6 months } \\
\hline Exclusive breastfeeding & 32 & 50.79 \\
\hline Mixte breastfeeding & 25 & 39.68 \\
\hline \multicolumn{3}{|l|}{ Vaccination } \\
\hline Up to date & 46 & 73.01 \\
\hline No up to date & 17 & 26.98 \\
\hline \multicolumn{3}{|l|}{ Medical background } \\
\hline Congénital heart disease & 8 & 12.69 \\
\hline HIV infection & 6 & 09.52 \\
\hline Psychomotor delay & 7 & 11.11 \\
\hline
\end{tabular}

The average consultation time was 18 days (range 1 to 120 days). The main reasons for consultation were cough (82.53\%) and breathing difficulties (58.73\%). On admission, $81 \%$ of the patients had fever, $93.64 \%$ had tachypnea and $58.73 \%$ had crackling rales at pulmonary auscultation. Hypoxemia was present in $58.73 \%$ of cases. Severe acute malnutrition has been found in 30 children (47.61\%). From a biological point of view, severe anemia was present in 79.36\%; hyperleukocytosis in $55.55 \%$ and an increase in C-reactive protein (CRP) in $60.38 \%$ of cases. Radiologically, opacity was found in 42 patients (66.66\%). These were alveolar opacities in 32 cases $(76.19 \%)$. These were bilateral in 19 cases (59.37\%) and no pleural effusion was found. The blood culture could be done in 36 patients, it returned positive in 3 cases or $8.3 \%$. The germs found out were: Haemophilus influenzae $b$ (one case), Burkholderia cepacia (two cases).

The main clinical, biological, bacteriological and radiological features are summarized in Table 2.

Beta-lactams were first-line prescribed in all patients: amoxicillin (61\%) and ceftriaxone (39\%). They were associated with gentamicin in $39 \%$ of cases. The average duration of antibiotic therapy was 13 days (range 3 to 30 days). The average time to obtain apyrexia was 3 days (range 1 to 7 days). The average 
Table 2. Clinical and biological characteristics of children.

\begin{tabular}{|c|c|c|}
\hline Variables & Frequency $(n=63)$ & Percent \\
\hline \multicolumn{3}{|l|}{ Consultation period } \\
\hline Average & 18 days & \\
\hline \multicolumn{3}{|l|}{ Reason for consultation } \\
\hline Respiratory difficulties & 37 & 58.73 \\
\hline Cough & 52 & 82.53 \\
\hline Alteration of general condition & 11 & 17.46 \\
\hline \multicolumn{3}{|l|}{ Clinical signs } \\
\hline Severe malnutrition & 30 & 47.61 \\
\hline Fever & 51 & 80.95 \\
\hline Tachypnea & 59 & 93.65 \\
\hline Crackling rattles & 60 & 95.23 \\
\hline Hypoxemia & 37 & 58.73 \\
\hline \multicolumn{3}{|l|}{ Biological signs } \\
\hline Severe anemia & 50 & 79.36 \\
\hline High CRP & 38 & 60.31 \\
\hline Leucoytosis & 35 & 55.55 \\
\hline \multicolumn{3}{|l|}{ Blood culture $(n=36)$} \\
\hline Positive & 3 & 08.33 \\
\hline Négative & 33 & 91.66 \\
\hline \multicolumn{3}{|l|}{ Radiological signs } \\
\hline No & 21 & 33.33 \\
\hline Alveolar opacities & 32 & 50.79 \\
\hline Alveolo-interstitial opacities & 10 & 15.87 \\
\hline
\end{tabular}

hospital stay was 9 days with extremes of 2 and 26 days. Six patients died or a case fatality rate of $9.52 \%$. The factors associated with mortality were age less than 14 months $(\mathrm{p}=0.08)$, adverse socio-economic conditions $(\mathrm{p}=0.0003)$, and the presence of hypoxemia at the entrance $(p=0.01)$. Table 3 presents the factors associated with mortality.

\section{Discussion}

This study aimed to determine the epidemiological and prognostic aspects of acute pneumonia in children from 1 to 59 months old hospitalized in a reference last-level service in Mali. The duration of the study could be a limit because it did not allow to appreciate the seasonality of the affection. It took place during the rainy, humid season (June to September) and the cool season between October and December, characterized by dry, cold and dusty winds. As parents were in charge of the X-ray, it was not performed in all patients. That might be one weakness of our work because the hospital frequency was probably underestimated in our study because of this mode of recruitment related to the 
Table 3. Analysis of factors associated with mortality.

\begin{tabular}{|c|c|c|c|}
\hline \multirow{2}{*}{ Factor } & \multicolumn{2}{|c|}{ Frequency } & \multirow{2}{*}{ p-value } \\
\hline & Died & Alive & \\
\hline \multicolumn{4}{|l|}{ Age } \\
\hline$<14$ months & 06 & 37 & 0.08 \\
\hline$\geq 14$ months & 00 & 20 & \\
\hline \multicolumn{4}{|l|}{ Sex } \\
\hline Male & 03 & 31 & 0.58 \\
\hline Female & 03 & 26 & \\
\hline \multicolumn{4}{|c|}{ Socio-economic conditions } \\
\hline Favorable & 00 & 44 & 0.0003 \\
\hline Unfavorable & 06 & 13 & \\
\hline \multicolumn{4}{|c|}{ Schooling of the mother } \\
\hline Yes & 02 & 41 & 0.55 \\
\hline No & 04 & 16 & \\
\hline \multicolumn{4}{|l|}{ Vaccination } \\
\hline Up to date & 05 & 41 & 0.48 \\
\hline No up to date & 01 & 16 & \\
\hline \multicolumn{4}{|l|}{ Tachypnea } \\
\hline Yes & 06 & 40 & 0.17 \\
\hline No & 00 & 17 & \\
\hline \multicolumn{4}{|l|}{ Hypoxemia } \\
\hline Yes & 06 & 26 & 0.01 \\
\hline No & 00 & 31 & \\
\hline \multicolumn{4}{|l|}{ Positive CRP } \\
\hline Yes & 04 & 34 & 0.63 \\
\hline No & 02 & 19 & \\
\hline \multicolumn{4}{|l|}{ Severe anemia } \\
\hline Yes & 06 & 44 & 0.23 \\
\hline No & 00 & 13 & \\
\hline
\end{tabular}

realization of the radiography. The frequency is lower than those found by Bakonde et al. (2.61\%) and Guedehoussou et al. (5.81\%) in Togo [17] [18]. In Tunisia, Tinsa found a hospital frequency of $3.6 \%$ [19].

In our series, severe forms of pneumonia predominated in infants under 1 year old (60\%). Our results are similar to those obtained by Ouédraogo et al. in Burkina and Ibraheem et al. in Nigeria, where the group from 0 to 2 years old represented $79.9 \%$ and $81.3 \%$ respectively [20] [21]. Infants are particularly exposed because of the immaturity of their immune and respiratory systems [19].

It is also during this period that food diversification and breastfeeding decline begin with the risks of diarrheal diseases and malnutrition. It also highlights the importance of protective immunoglobulin in breast milk [22]. The male sex was 
predominant in our study. It is considered a factor in the occurrence of pneumonia [23]. Our results are consistent with literature data [19] [21] [22]. This predominance of infants and boys has been asserted by Rudan et al. who indicate that about two thirds of pneumonia episodes occur in the first year of life, with a frequency of 1.5 to 1.8 times higher in boys than in girls [4]. The majority of patients lived in an unfavorable environment with mothers who were generally illiterate or poorly educated. A study carried out in Brazil study showed that pneumonia mortality was especially high in rural areas because of the difficulty of accessing health care [24].

In tropical areas with a high malaria endemicity where chronic diseases (malnutrition, anemia, HIV infection) are very common, pneumonia is most often seen in its invasive form. Severe malnutrition was observed in $47.61 \%$ of patients. We find similar results in many African authors [19] [21] [22] [25]. Several authors believe that it constitutes fertile ground for the emergence of severe forms of pneumonia [22] [26] [27]. The relative risk of pneumonia in malnourished children is three times higher than in well-nourished children [22] [27], hence the need for nutritional supplementation and routine education of mothers during immunization sessions [28] [27].

In our study, $10 \%$ of children were infected with the HIV human immunodeficiency virus. The authors agree that HIV contributes to the emergence of severe forms of pneumonia in children [4] [22] [28] [29]. These children are most often infected with atypical germs and strains resistant to the usual antibiotics [26]. In our study, $27 \%$ of children were not properly immunized according to the National Immunization Program. Some authors associate the poor immunization status with the risk factors for the occurrence and aggravation of respiratory diseases in children. According to Ujunwa et al., 50\% of people with low immunity would have severe forms of acute respiratory infections [22] while Tazinya et al. in their analysis did not find a significant association between vaccination and these [22] [28].

Pneumonia is most often manifested through two types of syndromes: infectious syndrome dominated by sudden onset fever, respiratory syndrome with functional signs (cough, dyspnea, chest pain, polypnea) and physical signs (condensation syndrome) [10] [30]. The majority of patients arrived in a chart of tachypnea (93.65\%) and fever (80.95\%). These serious forms could be explained by a delay in diagnosis and the high frequency of comorbidities, which are very frequent in our context [21] [26].

According to the literature, pneumonia is rarely diagnosed in a patient with normal temperature, heart rate, and respiratory rate [31]. The absence of abnormalities in the pulmonary examination, however, is not sufficient to eliminate pneumonia. Tachypnea is frequently reported in the literature as having a strong predictive value for pneumonia [19] [32]. Several clinical and field studies have shown that tachypnea is the most efficient clinical sign (70\%) for diagnosing pneumonia in malnourished children and children under 24 months old [19] 
[27] [33]. However, there may be false positives or false negatives and such an approach may lead to overdiagnosis, as demonstrated by an observational study in four Indian hospitals [34]. Therefore, the exclusive use of tachypnea to diagnose pneumonia is not recommended; in case of doubt, a chest X-ray or antibiotic treatment should be prescribed without delay [31] [35] [36]. In clinical practice, physicians generally tend to rely heavily on the presence of crackling rattles while this sign would have a high specificity (79\%), but a very low sensitivity $(46 \%)$ to make the diagnosis of pneumonia [27]. Therefore, its absence would not exclude the presence of pneumonia [27] [31].

According to Fancourt et al., $46 \%$ of the pneumonia cases defined according to the WHO criteria do not show any radiological evidence of pneumonia [37]. In our study, radiography was normal in $33.33 \%$ of cases. Most European guidelines recommend a frontal, inspiratory and standing chest X-ray to confirm any case of severe pneumonia [36] [38]. According to the former French Food Safety Agency (AFSSA) and other studies, there is no correlation between the observed images and the responsible micro-organism [36] [38]. In developing countries it is not easy to use radiography to confirm all cases of pneumonia [35]; WHO recommends it only in case of signs of seriousness, complications, unusual clinical signs, underlying chronic heart or respiratory disorder requiring intensive care, or associated with HIV infection [10]. Most of the symptoms and signs traditionally associated with pneumonia are not discriminating, the search for leukocytosis and the dosage of C-Protein Reactive (CRP) could reduce the abuse of pediatric antibiotics [33] [36] [38]. However, performing biological examinations should not delay treatment [36] and CRP is not useful in the management of simple cases of pneumonia [38]. The value of cytobacteriological examination of sputum $(\mathrm{ECBC})$ is limited because often contaminated by oropharyngeal germs [3] [38]. In a study conducted in Morocco in adults, on the interest of cytobacteriological examination of sputum in the management of bacterial pneumopathies in hospital, it was possible to isolate a germ in only $42.5 \%$ of cases [39]. Data from the literature show that viruses, Streptococcus pneumoniae and Haemophilus influenzae $\mathrm{b}$ are the predominant pathogens in community-acquired acute pneumonia in children $<5$ years of age [3] [4]. Given the low performance of complementary investigations for etiological diagnosis, a pragmatic approach of therapy with broad-spectrum antibiotics is generally used [34] [36].

Effective management of pneumonia cases is based on appropriate antibiotic therapy and supportive care, particularly oxygen therapy in the most severe cases [3] [40]. Although our practices were not fully in line with WHO guidelines [35], all our patients had received beta-lactams. In our series, the hospital mortality rate was $9.52 \%$ while it was only $0.8 \%$ in Brazil [24]. Factors associated with mortality were age less than 14 months $(\mathrm{p}=0.08)$, adverse socio-economic conditions $(p=0.0003)$ and presence of hypoxemia at entry $(p=0.01)$. In the study of Nascimento-Carvalho et al. in Brazil, the deaths of children with pneu- 
monia had occurred on a comorbid ground: cardiopathy, neuropathy, asthma, gastro-oesophageal reflux, congenital infection, hypothyroidism [24]. These pathologies have a negative influence on both the symptoms, the prognosis and the cost of treatment [24] [32] [35]. Reducing hospital mortality with pneumonia then requires continuing education of care staff for proper case management, improved access to health care and efforts to educate mothers about health

\section{Conclusion}

Pneumonia remains a major cause of morbidity and mortality in our context. The adverse socio-economic conditions favoring the non-respect of preventive measures such as vaccination and the late use of care, constitute a key prognostic factor. Further work should examine the determinants that the authorities could act to reduce the frequency of pneumonia and the deaths attributable to it.

\section{Conflicts of Interest}

The authors declare no conflicts of interest regarding the publication of this paper.

\section{References}

[1] Walker, C.L.F., Rudan, I., Liu, L., Nair, H., Theodoratou, E., Bhutta, Z.A., et al. (2013) Global Burden of Childhood Pneumonia and Diarrhoea. Lancet, 381, 1405-1414. https://doi.org/10.1016/S0140-6736(13)60222-6

[2] WHO (2014) Global Health Observatory Data Repository. http://apps.who.int/gho/data/view.main.CM100WORLD-CH9?lang=en

[3] Wagner, N., Gehri, M., Gervaix, A., et al. (2016) Prise en charge ambulatoire de la pneumonie communautaire de l'enfant: Mise au point. Revue Médicale Suisse, 12, 344-349.

[4] Rudan, I., Boschi-Pinto, C., Biloglav, Z., Mulholland, K. and Campbell, H. (2008) Epidemiology and Etiology of Childhood Pneumonia. Bulletin of the World Health Organization, 86, 408-416. https://doi.org/10.2471/BLT.07.048769

[5] WHO/UNICEF (2015) Countdown to 2015: A Decade of Tracking Progress for Maternal, Newborn and Child Survival. The 2015 Report, WHO-UNICEF, Geneva, New York.

[6] World Health Organization (2013) Ending Preventable Deaths of Children by Pneumonia and Diarrhea by 2015: Integrated Action Plan to Prevent and Combat Pneumonia and Diarrhea. World Health Organization, Geneva, 72 p. http://www.who.int/iris/bitstream/10665/95480/1/9789242505238_free.pdf

[7] Campbell, J.D., Sow, S.O., Levine, M.M. and Kotloff, K.L. (2004) The Causes of Hospital Admission and Death among Children in Bamako, Mali. Journal of Tropical Pediatrics, 50, 158-163. https://doi.org/10.1093/tropej/50.3.158

[8] Ministry of Health and Public Hygiene of the Republic of Mali, National Directorate of Health, Gabriel Touré Teaching Hospital (2017) Activity Report of the Department of Pediatrics. 37 p.

[9] Ayieko, P. and English, M. (2007) Case Management of Childhood Pneumonia in Developing Countries. Pediatric Infectious Disease Journal, 26, 432-440. https://doi.org/10.1097/01.inf.0000260107.79355.7d 
[10] World Health Organisation (2015) Mémento de soins hospitaliers pédiatriques : prise en charge des affections courantes de l'enfance- $2^{\text {ème }}$ éd. http://www.who.int/about/licensing/copyright_form/en/index.html

[11] Cherian, T., Mulholland, E.K., Carlin, J.B., Ostensen, H., Amin, R., de Campo, M., et al. (2005) Standardized Interpretation of Paediatric Chest Radiographs for the Diagnosis of Pneumonia in Epidemiological Studies. Bulletin of the World Health Organization, 83, 353-359.

[12] Chauliac, M., Bricas, N., Ategbo, E.A., Amoussa, W. and Zohoun, I. (1998) Alimentation out of the Home of Schoolchildren in Cotonou (Benin). Santé, 8, 101-108.

[13] Ag Bendech, M., Chauliac, M. and Malvy, D. (1996) Variability of Home-Based Dietary Practices of Families Living in Bamako (Mali) According to Socio-Economic Levels. Cahiers Santé, 6, 285-297.

[14] Ministry of Health and Public Hygiene of the Republic of Mali/National Directorate of Health (2017) Protocole de Prise en Charge Intégrée de la Malnutrition Aiguë au Mali. 204 p.

[15] Ministry of Health and Public Hygiene of the Republic of Mali/ Coordinating Unit of the Sectoral Committee for AIDS Control (2013) Politique et Protocoles de Prise en Charge antirétrovirale du VIH et du SIDA. 73 p.

[16] Carlier-Mercier, L. and Hennequet, A. (1991) Mémento Pédiatrie. 6ème Edition, Maloine, Paris, 270 p.

[17] Bakonde, B., Tatagan, K., Kessie, K., et al. (1998) Epidémiologie hospitalière des infections respiratoires aiguës (IRA) basses chez le nourrisson et l'enfant togolais. Médecine d' Afrique Noire, 45, 435-439.

[18] Guedehoussou, T., Atakouma, Y., Gbadoe, A.D., et al. (2010) Evaluation de la prise en charge des infections respiratoires aiguës chez les enfants de moins de 5 ans au CHU de Lomé (Togo). Journal de la Recherche Scientifique de PUniversité de Lomé, 12. https://www.ajol.info/index.php/jrsul/article/view/68029

[19] Tinsa, F., Boussetta, K., Gharbi, A., et al. (2009) Pneumopathies communautaires chez l'enfant. Tunisie Médicale, 87, 851-856.

[20] Ouédraogo, S.M., Toloba, Y., Ouédraogo, G., Badoum, G., Boncoungou, K., et al. (2010) Epidemio-Clinical Aspects of Bacterial Acute Infant Pneumopathies at Yalgado Ouédraogo University Health Center. Le Mali Medical, 25, 19-22.

[21] Ibraheem, R.M., Abdulkadir, M.B., Gobir, A.A. and Johnson, W.B.R. (2018) Socio-Demographic and Clinical Factors Predicting Time to Presentation for Children with Pneumonia in Ilorin, Nigeria. Alexandria Journal of Medicine, 54, 247-250. https://doi.org/10.1016/j.ajme.2017.05.013

[22] Ujunwa, F. and Ezeonu, C. (2014) Risk Factors for Acute Respiratory Tract Infections in Under-Five Children in Enugu Southeast Nigeria. Annals of Medical and Health Science Research, 4, 95-99.

[23] Aubry, P. and Gaüzère, B.A. (2018) Infections respiratoires aiguës. Médecine tropicale. Actualités 2017. Mise à jour le 23/01/2018. http://www.medecinetropicale.com

[24] Nascimento-Carvalho, C.M.C., Rocha, H., Rogerio, S.J. and Benguigui, Y. (2002) Childhood Pneumonia: Clinical Aspects Associated with Hospitalization or Death. Brazilian Journal of Infectious Diseases, 6, 22-28. https://doi.org/10.1590/S1413-86702002000100004

[25] Adedemy, J.D., Noudamadjo, A. and Agossou, J. (2017) Epidémiologie, clinique et facteurs associés aux infections respiratoires aiguës chez l'enfant de 0 - 5 ans au Centre Hospitalier Départemental de Parakou. Jafr pediatr genet med, No. 2, 47-53. 
[26] Onyango, D., Kikuvi, G., Amukoye, E. and Omolo, J. (2012) Risk Factors of Severe Pneumonia among Children Aged 2 - 59 Months in Western Kenya: A Case Control Study. Pan African Medical Journal, 13, 45.

[27] Palafox, M., Guiscafré, H., Reyes, H., Muñoz, O. and Martínez, H. (1991) Diagnostic Value of Tachypnoea in Pneumonia Defined Radiologically. Pediatrics, 88, 821-824.

[28] Tazinya, A.A., Halle-Ekane, G.E., Mbuagbaw, L.T., et al. (2018) Risk Factors for Acute Respiratory Infections in Children under Five Years Attending the Bamenda Regional Hospital in Cameroon. BMC Pulmonary Medicine, 18, 7. https://doi.org/10.1186/s12890-018-0579-7

[29] Mayaud, C., Parrot, A., Houacine, S., Denis, M. and Akoun, G. (1992) Épidémiologie des germes responsables des infections communautaires des voies respiratoires inférieures. Médecine et Maladies Infectieuses, 22, 130-139.

https://doi.org/10.1016/S0399-077X(05)81461-1

[30] Bourillon, A. (2011) Infections des voies respiratoires basses. In Pédiatrie pour le praticien. 6ème Edition, Elsevier/Masson, Paris, 467-474.

[31] Brander, P. and Garin, N. (2011) Utilité de l'anamnèse et de l'examen clinique dans le diagnostic de la pneumonie. Revue Médicale Suisse, 7, 2026-2029.

[32] Bayisa, G., Likey, Y. and Mosisa, B. (2017) Clinical Treatment Outcomes of Pneumonia among Hospitalized Pediatric Patients in Nekemte Referral Hospital, Pediatrics Ward, Ethiopia. World Journal of Pharmacy and Pharmaceutical Sciences, 6, 68-84.

[33] Hopstaken, R.M., Muris, J.W.M., Knottnerus, J.A., et al. (2003) Contributions of Symptoms, Signs, Erythrocyte Sedimentation Rate, and C-Reactive Protein to a Diagnosis of Pneumonia in Acute Lower Respiratory Tract Infection. British Journal of General Practice, 53, 358-364.

[34] Rodrigues, C.M.C. and Grovesc, H. (2018) Community-Acquired Pneumonia in Children: The Challenges of Microbiological Diagnosis. Journal of Clinical Microbiology, 56, e01318-17.

[35] World Health Organization (2006) Pneumonia, the Forgotten Killer of Children. UNICEF/WHO, Geneva.

[36] Agence Française de Sécurité Sanitaire des Produits de Santé (2005) Antibiothérapie par voie générale en pratique courante dans les infections respiratoires basses de l'adulte et de l'enfant. Argumentaire, $84 \mathrm{p}$.

http://www.infectiologie.com/UserFiles/File/medias/_documents/consensus/2005-i nfVRB-argu-afssaps.pdf

[37] Fancourt, N., Knoll, M.D., Baggett, H.C., Brooks, A., et al. (2017) Chest Radiograph Findings in Childhood Pneumonia Cases from the Multisite PERCH Study. Clinical Infectious Diseases, 64, S262-S270. https://doi.org/10.1093/cid/cix089

[38] Harris, M., Clark, J., Coote, N., Fletcher, P., Harnden, A., McKean, M., Thomson, A., British Thoracic Society Standards of Care Committee (2011) British Thoracic Society Guidelines for the Management of Community Acquired Pneumonia in Children: Update 2011. Thorax, 66, ii1-ii23.

https://doi.org/10.1136/thoraxjnl-2011-200598

[39] Zaidane, S., Zaghba, N., Benjelloun, H. and Yassine, N. (2017) Intérêt de l'examen cytobactériologique des expectorations (ECBE) dans la prise en charge des pneumopathies bactériennes en milieu hospitalier. Revue des Maladies Respiratoires, 34, A105. https://doi.org/10.1016/j.rmr.2016.10.237 
[40] Mathura, S., Fuchsb, A., Bielickia, J. and Van Den Anker, J. (2018) Antibiotic Use for Community-Acquired Pneumonia in Neonates and Children: WHO Evidence Review. Paediatrics and International Child Health, 38, S66-S75.

https://doi.org/10.1080/20469047.2017.1409455 